\title{
Impact of Internal Cognitive Factors on Social Entrepreneurial Intention
}

\author{
Syed Mazahir kazmi \\ School of Public Affairs, University of Science and Technology of China, China \\ E-mail: mazahir@mail.ustc.edu.cn

\begin{abstract}
Ali Hammad (Corresponding author)
School of Public Affairs, University of Science and Technology of China, China E-mail: Alihamad@mail.ustc.edu.cn
\end{abstract}

\begin{abstract}
Arslan Ahmed
School of Public Affairs, University of Science and Technology of China, China E-mail: arslan@mail.ustc.edu.cn
\end{abstract}

Salman zulfiqar

Comsats university Islamabad, Islamabad

E-mail: Salmanzulfiqar@cuisahiwal.edu.pk

Received: November 16, 2018 Accepted: December 14, 2018 Published: January 14, 2018

doi:10.5296/ber.v9i1.14222 URL: https://doi.org/10.5296/ber.v9i1.14222

\begin{abstract}
This aim of the study is to recognize the social entrepreneurial intention among youth who are the business undergraduate, graduate and professional students in Pakistan and China using the theory of planned behavior. 355 respondents from business Pakistani and Chinses universities using 54 item questionnaire. Systematized random sampling was employed to collect data. $72 \%(\mathrm{~N}=256)$ of the respondents were male, and $28 \%(\mathrm{~N}=98)$ were female, and most of the respondent's age range between 20 to 35 of age. To measure the intention and
\end{abstract}


attitude of youth towards social entrepreneurship using emotional intelligence and moral obligation with Theory of planned behavior. The result demonstrates that the hypothesized research model of study describes $46 \%$ of the variance, which explains social entrepreneurship intention. Results indicate that emotional Intelligence a significant relationship with self-efficacy and attitude where it has a positive relationship with social norms but is not significant. Conversely, the moral obligation has a significant positive relationship with attitude, self-efficacy and social norms which leads towards social entrepreneurship. Research study focuses and contributes to the social entrepreneurship literature using new antecedents using emotional intelligence and moral obligation to measure the development of social entrepreneurial intention.

Keywords: Moral Obligation, Emotional Intelligence, Attitutde, Self-efficacy, Intention

\section{Introduction}

For the last two decades, entrepreneurship has appeared as the most significant pillar of economic growth around the world. Kirkley (2016) states that for national growth and economy encouragement and establishment of small and medium new ventures is suitable for country development. Cornelissen \& Clarke (2010) described that entrepreneurial activities have a positive impact on the domestic economy as well as on country bases. Countries in which entrepreneurial activities and new ventures are encouraged, their economic cycle revolve due to which people get employment and money keep circulating in the economy. Entrepreneurial ventures are essential to solve the problem and bring sustainable development in the society. Sustainable development is the environmental, technological and social development of the society and community. Environmental development is that entrepreneurs change the structure of the market; due to which new entrepreneurs get opportunities to contribute to the advancement of the domestic economy by launching new ideas and create ventures. Entrepreneurs recognize opportunities by targeting segment in the market, satisfy needs and wants of the segment. Social context, entrepreneur's give a solution to the most important problem that today's societies are facing around the world i-e unemployment, poverty, and slow economic growth. Entrepreneurial venture facilitates millions of people that include women and minorities to get benefited from economic success. Now a day's researchers are emphasizing a new aspect of entrepreneurship that is social entrepreneurship.

Social entrepreneurship is defined as an entrepreneur's emphasis on social and community problems. They generate novel enterprises, create and design social planning and organize resources to deal with these social problems. According to these argument social entrepreneurship is the future for the countries this not helps to deal with economic crisis, but it also aims to provide innovative resolutions to unsettled social problems. The value given to Social problem is the key which allows and encourage the individual to make a mission to serve societies and communities and work for their well-being. Social entrepreneurs are the one who creates a venture with the aim to bring systematic social change through the development of new product, service or processes (Trivedi, 2010). According to Weerawardena \& Mort (2006), Social entrepreneurs identify and address the 
social problem in their communities and societies. According to Haugh (2005) social entrepreneurial intention is necessary to study to know what is a process and what are the necessities of entrepreneurs. Mehdivand et al. (2012) state that individual cognitive characteristics are the key to the development and creation of social entrepreneurial venture. The cognitive process that let people understand and identify unresolved and unanswered problems faced by the society. Lumpkin \& Lichtenstein (2005) explain social entrepreneurial cognition as the capability of an individual to identify business ideas, add values, implement them and get a good response from the customer. Individual identify opportunities when they understood and recognized the problem faced by the society and how to act upon them to get positive results.

In this capitalist world, there is an unequal distribution of wealth and resources among the population. According to word bank in total 1 percent of the population of the world holds 50 percent of world resources and wealth. In the present rich are getting richer and the poor are getting poorer. Uneven distribution of resources and wealth are characteristic of the capitalist system, and an only sustainable solution to solve these problems is social entrepreneurship. Social entrepreneurship can be implemented in the form of micro-financing, crowdfunding, improve literacy rate, support healthcare, and come up with innovative and creative ideas which helps in creating a sustainable environment and society. Social Entrepreneurship is an unconventional business model that generates outcomes which helps in solving society and community problems. It is about aiming at tackling social problems and come up with innovative and creative solutions to transform society. Social entrepreneurship helps in bringing about positive changes in the social, political and economic situation of low-income families. Social entrepreneurs mobilize and built arrangements of resources to deal with untapped problems of the public and society. Social entrepreneurs are passionate, committed and visionary individuals who pursue for opportunities to have a positive impact on society.

\section{Theoretical Implication}

Ajzen (1991), presents a theory of planned behavior which includes three important ascendants that include self-efficacy, attitude and subjective norms. Theory of Planned Behavior (TPB) is employed in different types of research study to measure intention of individual towards activities like in transport research (Chen 2016), medical information (Hsieh 2015), behavioral science (Kim 2014), biological economics (Litvine et al. 2014), environmental sciences (Deng et al. 2016), applied psychology (Hawley \& Williford 2015), food quality (Lorenz et al. 2015), computer study (Liao et al. 2007) and in many other fields. In this paper, TPB is used to measure the intention of individual towards social entrepreneurship using social norms, self-efficacy, perceived control behavior, emotional intelligence, and moral obligation. Emotional intelligence and moral obligation are ascendants which affect the attitude, subjective norms and self-efficacy of individuals which leads to the intention of individuals towards social entrepreneurship.

\subsection{Intention towards Social Entrepreneurship}

The intention is readiness and willingness of an individual to perform particular task within particular environment and society. The success of an individual relies on willingness as well 
as the ability of an individual to perform a task (Othman, Hashim, \& Wahid, 2012). Social entrepreneurship is a new and novel idea and individual intention towards it. Social entrepreneurs put their effort to create a sustainable public environment in which all the people get equal opportunities to earn and spend standard living. Schumpeter's $(1934,2004)$ presents entrepreneurship theory which focuses on economic growth and entrepreneurs profits and success whereas; social entrepreneurship theory emphases on the social and economic development of the society (Ebrashi, 2010). Social entrepreneurs aim to create venture for social change (Nicholls, 2006). Intention towards social entrepreneurship depends upon their ability to learn for environment and society and utilize their cognitive capability and ability to observe the environment and extract an idea from it.

\subsection{Attitude towards Entrepreneurship}

Kinicki \& Krietner (2009) is the psychosomatic tendency of an individual to assess the behavior in favor and disfavor while valuing a particular situation. Harjer and Habib (2013) describe attitude as the responsive reaction of an individual after indulging or having experience with specific status quo (Zimmerman, 2008) strong attitude would affect the behavior. Expectations and beliefs of individuals that result in positive or negative action attitude in certain situation; further attitude is transformed into intent and subsequently, act towards certain circumstances (Ajzen \& Fishbein, 1980). Applied and observation information and knowledge is important to bring about the changes in the attitude of individuals, which motivates to change in intentional behavior.

\subsection{Subjective Norms}

Subjective norms are the course of action that is considered appropriate and suitable within a society or group of individuals (Cialdini et al., 1991). It is the acceptance of a society that supports or approve specific actions and activities in a particular situation. Subjective norms are the public's opinion which intern encourage or discourage individual to behave in a specific manner in a given situation(Elster, 1989). According to Primack et al. (2007) and Zhao et al. (2006) clarify subjective norms as the social pressure that effect that individual attitude and intention towards certain situation these includes referents i-e relatives, friends, teachers, colleagues, classmates. Subjective norms are the views and thoughts that be shared and sustained by society's endorsement (Kandori, 1992). Baumeister and Leary (1995) Subjective norms are unwanted and undesirable emotions like guilt, humiliation, and embarrassment if one breakdowns rules. Subjective norms are the beliefs, thoughts, and values that impact individual entrepreneurial activities (Aparicio et al. 2015) (Becker \& Woessmann, 2009). Kautonen \& Tornikoski (2010) and Shane (1993) explains that in societies individuals have less intention towards social entrepreneurship and new venture creation where their uncertainty avoidance is high. Uncertain avoidance significantly affects innovation risk-taking (Kautonen \& Tornikoski, 2010) and (Yordanova \& Tarrazon, 2010).

\subsection{Entrepreneurial Self-Efficacy}

Self-efficacy is the capability of an individual to control over circumstances in a given situation (Solesvick, 2012). Icek Ajzen (2002) explains self-efficacy is people control over 
their actions or behavior. Rotter (1966) \& Conner and Armitage (1998) Self-Efficacy is considered a predecessor of intention; if people are motivated, they have strong intention towards entrepreneurship. Entrepreneurial self-efficacy is that an individual can exploit cognitive resources that motivate and allow individuals to control the events which happen in their life. In other words, self-efficacy strengthen the belief of an individual on his capability and aptitude to perform duties and task to be successful in achieving their goals (Chen et al., 1998). When individuals believe that they have essential abilities and expertise to produce the desired results and adopt an attractive carrier option (Zhao et al., 2005). Tsordia \& Candidate (2015) urged that self-efficacy significantly affect that attitude and intention of individual towards entrepreneurial activities. Krueger et al. (2000), self-efficacy is the predecessor of intent towards entrepreneurial activities.

\subsection{Emotional Intelligence}

Thorndike (1937), define emotional intelligence as the degree to which individual's capability to accomplish goals using emotional feelings. According to Salovey \& Mayer (1990) there is two school of thoughts which explains emotional intelligence, first explains that mental ability models and (Gardner, 2008) explain the mixed approach. Mental ability model explains the cognitive and emotional intelligence of an individual, which states that the capability of an individual to recognize and control its information. Another class of thought, emotional intelligence, is individual's attribute and characteristics to manage their need for achievement and flexibility and their relationship with the emotional state (Boren, 2010). Numbers of researchers study the effect of emotional intelligence on individual intention towards social entrepreneurship. Zampetakis et al. (2009) examined emotional intelligence as the ascendant variable which may help an individual in developing opportunity recognition behavior i-e creativity, proactivity and on the attitude of individual towards entrepreneurship.

Emotional intelligence has not been used to predict social entrepreneurial intention. Emotional intelligence is considering as a significant predictor towards for social entrepreneurial intention, which provides an individual to come up with creative and innovative solutions to solve social problems. Emotional feelings and thoughts provide entrepreneurs competitive edge over others. Therefore, in this study, the researcher uses emotional intelligence as the predictor to have an individual intention towards social entrepreneurship. By the above literature explained following hypothesis is formed

\subsection{Moral Obligation}

Bryant (2009), define moral obligation as the tendency of an individual to help each other by keeping themselves within religious limits. Fishbein (1967) adopted moral obligation to study behavioral attitude, self-efficacy and subjective norms to foresee the intention of the individual. In the context of social entrepreneurship, moral obligation, entrepreneurs are fully committed to creative and innovative ideas and morally sense to purse idea Beugré (2016). Mair \& Martí (2006) measures the social entrepreneurial intention using construct i-e moral obligation. According to Roberts \& Woods (2000) and Hendry (2004), moral obligation is the key determinant that differentiates between entrepreneurship and social entrepreneurship. An individual with high moral values has an intention towards social entrepreneurship. An 
individual with social entrepreneurial intention has a sense of responsibility, duty and are motivated to serve the society. Social entrepreneurs work for the betterment of the society and also helps in developing the economy of the country (Thompson, 2008). According to Boschee (1995) describes social entrepreneurs not only have profit motives but also a have a moral commitment towards society. Mair and Noboa (2006) practices moral obligation to measure social entrepreneurial intention. Haines, Street, \& Haines (2008) used moral obligation construct as the decision-making process that motivates entrepreneurs to make a decision based on the moral judgment.

\section{Research Methodology and Data Collection}

To conduct this research study data is collected from universities student in Pakistan. There are some techniques which are used to collect and manage the data. These techniques include self- administrated questionnaire and online survey software techniques like survey monkey and Google Docs. For this research thesis, secure and cost-effective methods were used to collect data from students. To collect data from the respondent's web-based survey technique were used as it is cost and time effective. Pilot testing was executed to test the reliability and validity of the questionnaire that's why the pilot test conducted before collecting the data. The primary purpose of the pilot study is to upgrade the questionnaire according to the feedback given by respondents (Bell, 2005; Fink, 2003). Web survey link was sent to respondents using email and through Smartphone's application i-e WeChat and WhatsApp. More 495 questionnaires circulated among students out of which 360 questionnaires were found useable constituted of $69.01 \%$ of response rate.

Table 1. Demographic Information

\begin{tabular}{|l|l|l|l|}
\hline Category & & Frequency & Percentage \\
\hline Gender & Female & 125 & $34.7 \%$ \\
& Male & 235 & $65.2 \%$ \\
\hline Age & $20-25$ & 65 & $18.05 \%$ \\
& $26-30$ & 150 & $41.66 \%$ \\
& $31-35$ & 95 & $26.38 \%$ \\
& $35-40$ & 50 & $13.8 \%$ \\
\hline \multirow{5}{*}{ Education } & Under-Graduate & 85 & $23.61 \%$ \\
& Graduate & 101 & $28.05 \%$ \\
& Post-Graduate & 116 & $32.22 \%$ \\
& Professional Degree & 58 & $16.11 \%$ \\
\hline
\end{tabular}

7 Likert scales questionnaire used where one strongly disagrees, four neutrals and seven strongly agree. To make sure the validity and reliability of constructs questionnaire were adapted from for research studies like (Kuen-Hung, \& Chen-Yi, 2014) (Solesvik et al., 2012)(Gabriella Cacciotti et al., 2016) with revisions of words and sentences by the needs of the research.

\subsection{Analysis}

AMOS-21 an important software was used to perform the Structural Equation Modeling 


\section{MIN Macrothink}

Business and Economic Research ISSN 2162-4860 2019, Vol. 9, No. 1

(SEM) method to perform statistical analysis and model test. AMOS software helps researchers to conclude results using multivariate analysis (Hair, Black, Basin, \& Anderson, 2010). SEM is a three-step method of analysis. The first step is the dimension reduction method which includes exploratory factor analysis, a number of tests were conducted to examine the appropriateness of data. Second step is to perform validity and reliability of data, for this confirmatory factor tests were performed in which researcher measure convergent validity, correlation, Cronbach alpha, average variance extracted and other tests. Third step, structural equation modeling was performed in which measurement and structural models are tested (Anderson \& Gerbing, 1988). Structural Equation Modeling (SEM) is becoming popular technique for researchers belong to different disciplines, they are practically implementing these techniques to legitimize their research results (Hooper et al., 2008). In order to examine the fitness of model, researcher observe the goodness of fit indices. Most commonly observed indices include Chi-square $\left(X^{2} / d f\right)$, Tucker-Lewis index (TLI), Incremental fit index (IFI), comparative fit index (CFI), Root mean square root error of approximation ( RMSEA) and, Normed Fit Index (NFI). Threshold of Goodness of fit indices are Chi-square should have the range between 2.0 and 5.0. RMSEA value ranges between 10 and .030. NFI and CFI values of indices can range between 0.90 and 0.95 respectively.

It is essential to validate the data before analyzing the measurement and structural model. For this purpose, convergent validity was evaluated by considering the factor loading, Cronbach Alpha, Composite reliability (CR) and Average Variance Extracted (AVE) values that they remain in the suitable range. Threshold, values for benchmark values factor loadings, Cronbach Alpha, CR, and AVE, is 0.7, 0.7, 0.7 and 0.5 respectively.

Table 2. Values of Factor loading, Cronbach Alpha, CR and AVE

\begin{tabular}{|l|l|l|l|l|l|}
\hline Constructs & Items & Factor Loadings & Cronbach Alpha & CR & AVE \\
\hline Entrepreneurial Attitude & EA 1 & .853 & 0.855 & 0.883 & 0.715 \\
\hline & EA 2 & .801 & & & \\
\hline & EA 3 & .818 & & & \\
\hline Moral Obligation & MO 1 & .845 & 0.789 & 0.794 & 0.565 \\
\hline & MO 2 & .761 & & & \\
\hline & MO 3 & .788 & & & \\
\hline Social Entrepreneurial Intention & EIN1 & .802 & 0.823 & 0.815 & 0.595 \\
\hline & EIN2 & .763 & & & \\
\hline & EIN3 & .800 & & & \\
\hline Self-Efficacy & SE1 & .771 & 0.778 & 0.781 & 0.549 \\
\hline & SE2 & .827 & & & \\
\hline & SE3 & .722 & & & \\
\hline Emotional Intelligence & EI1 & .737 & 0.848 & 0.852 & 0.592 \\
\hline & EI2 & .883 & & & \\
\hline & EI3 & .833 & & & \\
\hline & EI4 & .829 & & & \\
\hline Subjective Norm & SN1 & .870 & .870 & 0.871 & 0.628 \\
\hline
\end{tabular}




\begin{tabular}{|l|l|l|l|l|l|}
\hline & SN2 & .847 & & & \\
\hline & SN3 & .849 & & & \\
\hline & SN4 & .823 & & & \\
\hline
\end{tabular}

As shown in table\#2 Factor loadings, Cronbach Alpha, CR values are above 0.7, and AVE values for all constructs are above 0.5 . Therefore, results in table \# 2 show good convergent validity.

Table 3. Constructs correlation and the square root of AVE

\begin{tabular}{|l|l|l|l|l|l|l|l|l|}
\hline & Constructs & AVE & $\mathbf{1}$ & $\mathbf{2}$ & $\mathbf{3}$ & $\mathbf{4}$ & $\mathbf{5}$ & $\mathbf{6}$ \\
\hline 1 & Moral Obligation & 0.565 & $\mathbf{0 . 7 5 1}$ & & & & & \\
\hline 2 & Entrepreneurial Subjective norm & 0.628 & 0.087 & $\mathbf{0 . 7 9 2}$ & & & & \\
\hline 3 & Emotional Intelligence & 0.592 & 0.158 & -0.004 & $\mathbf{0 . 7 7 0}$ & & & \\
\hline 4 & Entrepreneurial Attitude & 0.715 & 0.474 & -0.023 & 0.300 & $\mathbf{0 . 8 4 6}$ & & \\
\hline 5 & Social Entrepreneurial Intention & 0.595 & 0.412 & 0.020 & 0.007 & 0.458 & $\mathbf{0 . 7 7 1}$ & \\
\hline 6 & Entrepreneurial Self-efficacy & 0.549 & 0.368 & -0.011 & 0.146 & 0.500 & 0.471 & $\mathbf{0 . 7 4 1}$ \\
\hline
\end{tabular}

According to Fornell and Larcker (1981), additionally, discriminate validity can be determined by comparing the association between constructs correlation and the square root of AVE. AVE square root of construct greater than the constructs correlation, this shows good discriminate validity (Table 3 )

Table 3. Goodness-of-fit model

\begin{tabular}{|l|l|l|}
\hline Indices & Measurement Model & Structural Model \\
\hline X2 & 1.978 & 2.521 \\
\hline GFI & .911 & 0.956 \\
\hline AGFI & .882 & .901 \\
\hline CFI & .952 & .939 \\
\hline NFI & .908 & .906 \\
\hline RMSEA & .052 & .065 \\
\hline
\end{tabular}

According to the above references, indices for this research measurement and structural model show the goodness-of-fit model where values of chi-square, GFI, AGFI, CFI, NFI, and RMSEA are shown in table\#4. After verification of measurement and structural model, in next step is to test the hypothesis.

Table 4. Results of Hypothesized Paths

\begin{tabular}{|l|l|l|l|l|l|}
\hline \multicolumn{2}{|l|}{ Hypothesized Paths } & Coefficients & t-value & P-value \\
\hline Emotional Intelligence & $\rightarrow$ & Attitude & .362 & 9.751 & $* * *$ \\
\hline Emotional Intelligence & $\rightarrow$ & Self-efficacy & .427 & 10.594 & $* * *$ \\
\hline Emotional Intelligence & $\rightarrow$ & Subjective Norm & .071 & 1.277 & .201 \\
\hline Moral Obligation & $\rightarrow$ & Attitude & .196 & 4.979 & $* * *$ \\
\hline Moral Obligation & $\rightarrow$ & Self-efficacy & .133 & 2.278 & .023 \\
\hline
\end{tabular}




\begin{tabular}{|l|l|l|l|l|l|}
\hline \multicolumn{2}{|l|}{ Hypothesized Paths } & Coefficients & t-value & P-value \\
\hline Moral Obligation & $\rightarrow$ & Subjective Norm & .128 & 2.176 & .030 \\
\hline Attitude & $\rightarrow$ & Entrepreneurial Intention & .161 & 3.621 & $* * *$ \\
\hline Self-efficacy & $\rightarrow$ & Entrepreneurial Intention & .247 & 6.765 & $* * *$ \\
\hline Subjective Norm & $\rightarrow$ & Entrepreneurial Intention & -.106 & -2.928 & .003 \\
\hline
\end{tabular}

According to research outcomes, emotional intelligence significant impact attitude and self-efficacy of the individual which leads individual social entrepreneurial intention $(\beta=.362$, $\mathrm{p}<.001)$ and $(\beta=.472, \mathrm{p}<.001)$ whereas emotional intelligence is positively associated with subjective norms but not significant $(\beta=.071, \mathrm{p}>.001)$. Moral Obligation is positively impacted with an attitude, self-efficacy, and subjective norm of individual toward social entrepreneurship $(\beta=.196, \mathrm{p}<.001)$ and $(\beta=.133, \mathrm{p}<.01)$ and $(\beta=.128, \mathrm{p}<.01)$ respectively. Attitude, Self-efficacy and Subjective Norm of individual toward social entrepreneurship intention $(\beta=.161, p<.001),(\beta=.247, p<.001)$ and $(\beta=-.106, p<.01)$ respectively.

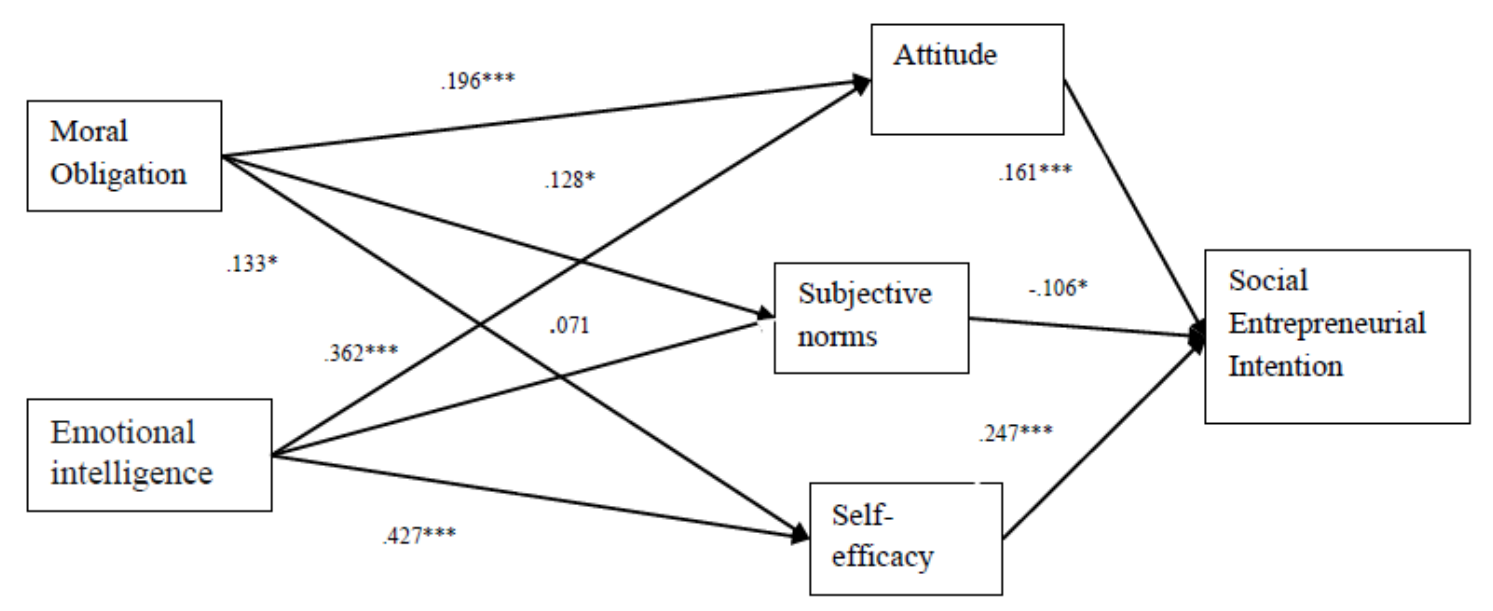

Figure 1. Result of Hypothesized model

\section{Discussion}

The primary objective of research paper study is to measure the impact of moral obligation and emotional intelligence on youth social entrepreneurial attitudes and intentions. To achieve the research milestone, structural equation modeling (SEM) was employed to measure the intention of youth towards certain task (Hockerts 2015; Zampetakis et al. 2009). This approach is useful because enhances the reliability and validity of the results and also allow researchers to interpret results well and build theories on it. Reason to choose social entrepreneurship as the topic of research is that there are huge gap and few empirical studies conducted in this field. This empirical study examines that emotional intelligence, moral obligation are essential and significant precursors of social entrepreneurial intentions. Results show that there is a significant association between emotional intelligence the antecedent and social entrepreneurial intentions, this proposes that the ability of an individual to evaluate and assess the situation using cognitive emotions which involves identifying and solving the problems of society. Emotional intelligence is a pro-social behavior that let an individual 
responsibility toward the social problem.

Results show that moral obligation also shows that healthy relationship with attitudes and perceived behavioral control whereas it has a weak and non-significant relationship with the subjective norm. Moral obligation boosts the ability of an individual to recognize, understand and respond to the feeling and emotions of another individual (Batson, 1998; Barker, 2003). Moral empathy considered the closest connection between two human beings. (Ruskin, Seymour, \& Webster, 2016; Segal E. A., 2011; Hoffman, 2000). Moral empathy is considering as the building block for positive social behavior and action of individual towards betterment and benefits for the society. Many researchers argue that moral empathy is an essential determinant which develops a healthy relationship and promotes helping and positive social behavior among humans. The absence of moral empathy is destructive for behavior and has a negative impact on the relationship between human beings.

Social entrepreneurs are the individuals who provide innovative and novel solutions to deal with the problems and troubles faced by societies. Social entrepreneurs employ creative ways to accomplish and start a venture with the aim to solve a community problem. This research paper tried to examine the relationship between emotional intelligence (the cognitive the constructive variables) and the moral obligation of youth with the aim to adopt social entrepreneurship as a career in future. This research paper contributes theoretically and empirically test the influence of emotional intelligence and moral obligation in order to foresee entrepreneurial intention formation. The study concludes that emotional intelligence and moral obligation influence the attitude and self-efficacy of youth which leads towards the social entrepreneurial intention. Thus support the hypothesis.

Results of this study help policymakers and researchers to initiate courses at every level of educational institutes from school till universities, this helps students in developing emotional intelligence and, also helps them to understand their moral obligation. This course of action may allow youth to develop understand the society problems and also help them in identifying and categorizing values and potential that help an individual in developing social entrepreneurial intention. Policy makers and educational scientists need to develop the in-depth understanding of the antecedents for social entrepreneurial intentions which encourage individuals to acquire knowledge and involved themselves in social entrepreneurship. Social entrepreneurial firms have appeared as an essential business mechanism which can deal with the unequal distribution of resources and inequities in society. Social entrepreneurship assists society to recognize the problems faced by societies and entrepreneurs offer products, services, and processes which allow needy and poor to interact with the market as active participants. To spread awareness and encourage youth to adopt social entrepreneurship as a career there is need to encourage and ensure that universities and academic institutions launch courses which include classes, seminars, practically perform activities by indulging with social organizations and through online distance education in order promote social entrepreneurship in the country.

\section{Limitation}

The objective and purpose of this study are to provide empirical evidence and understanding 
that emotional intelligence and moral obligation effects individual in developing youth attitudes and intention towards social entrepreneurship. However, there are limitations associated with this research study and which help in exploring future research. The first limitation is that data is collected from the students of business management filed of universities where students of the technical field are not targeted this may not give the generalized findings. In this study hypothesized model offers room for further modifications and more antecedents variables can be added to have a better understanding about the social entrepreneurial intention of youth. A cross-section research was performed in which data is collected from respondents once; longitudinal research study can help in understanding entrepreneurial intention in a more formal manner. However, this research paper is helpful in understanding the phenomenon of social entrepreneurship as this phenomenon is new and increasing research field. Policy makers and academicians are struggling to provide the gateway to youth to have an intention towards entrepreneurship while keeping in mind the wellbeing of the society.

\section{References}

Ajzen, I. (1991). The theory of planned behavior. Journal of Organizational Behavior and Human Decision Processes, 179-211.

Ajzen, I., \& Fishbein, M. (1980). Understanding Attitudes and Predicting Social Behaviour. NJ: Prentice-Hall, Englewood Cliffs.

Anderson, J., \& Gerbing, D. (1988). Structural equation modeling in practice: a review and recommended two-step approach. Psychological Bulletin, 103(3), 411-423.

https://doi.org/10.1037/0033-2909.103.3.411

Arbuckle, J. (2003). Amos 5.0 Update to the AMOS User's Guide. Cicago: Small Waters Corp.

Bandura, A., Reese, L., \& Adams, N. E. (1982). Microanalysis of action and fear arousal as a function of differential levels of perceived self-efficacy. Journal of Personality and Social Psychology, 5, 5-21. https://doi.org/10.1037/0022-3514.43.1.5

Barker, R. (2003). The social work dictionary. Washington DC: DC: NASW Press.

Barrettx, P. (2007). Structural Equation Modelling: Adjudging Model Fit. Personality and Individual Differences,, 42(5), 815-824. https://doi.org/10.1016/j.paid.2006.09.018

Batson, C. (1998). Altruism and Prosocial Behavior. New York: McGraw-Hill.

Baumeister, R., \& Leary, M. (1995). The need to belong: desire for interpersonal attachments as a fundamental human motivation. Psychological Bulletin.

https://doi.org/10.1037/0033-2909.117.3.497

Becker, S., \& Woessmann, L. (2009). Was weber wrong? A human capital theory of protestant economic history. Q. Journal Economic, 124(2), 531-596.

https://doi.org/10.1162/qjec.2009.124.2.531 
Bell, J. (2005). Doing Your Research Project. Buckingham: Open University Press.

Beugré, C. (2016). Social Entrepreneurship: Managing the Creation of Social Value. Routledge. https://doi.org/10.4324/9780203442609

Boren, A. (2010). Emotional Intelligence: The secret of successful entrepreneurship ? Leadership in Agriculture, 54-61.

Boschee, J. (1995). Social entrepreneurship: Some nonprofits are not only thinking about the unthinkable, they're doing it - Running a profit. Across the Board, The Conference Board Meeting,, (pp. 1-25.).

Bryant, P. (2009). Self-regulation and moral awareness among entrepreneurs. Journal of Business Venturing, 505-518.

Carsrud, A., \& Brannback, M. (2009). Understanding the entrepreneurial mind-opening the black box. London : Spring Dordrecht Heidelberg.

Chell, E., Nicolopoulou, K., \& Karatas-Ozkan, M. (2010). Social entrepreneurship and enterprise: International and innovation perspectives. Entrepreneurship \& Regional Development, 22(6), 485-493. https://doi.org/10.1080/08985626.2010.488396

Chen, C., Greene, P., \& Crick., A. (1998). Chen, C., P. Greene and A. Crick. 1998. Does entrepreneurial self-efficacy distinguish entrepreneurs from managers? . Journal of Business Venturing, 13, 295-316. https://doi.org/10.1016/S0883-9026(97)00029-3

Cialdini, R., Kallgren, C., \& Reno, R. (1991). A focus theory of normative conduct: A theoretical refinement and reevaluation of the role of norms in human behavior. Advances in Experimental Social Psychology, 24, 201-234.

https://doi.org/10.1016/S0065-2601(08)60330-5

Coduras, A., Saiz-Alvarez, J. M., \& Ruiz, J. (2016). Measuring readiness for entrepreneurship:An information tool proposal. Journal of Innovation \& Knowledge, 99-108.

Conner, M., \& Armitage, C. J. (1998). Extending the theory of planned behavior: a review and avenues for further research. Journal of Applied Social Psychology, 15, 1429-1469. https://doi.org/10.1111/j.1559-1816.1998.tb01685.x

Cornelissen, J., \& Clarke, J. (2010). Imagining and rationalising opportunities: inductive reasoning and the creation and justification of new ventures. Academy of Management Review, $35(4), 539-557$.

Domenico, D., Haugh, H., \& Tracey, P. (2010). Social bricolage: Theorizing social value creation in social enterprises. Entrepreneurship Theory and Practice, 34(4), 681-703. https://doi.org/10.1111/j.1540-6520.2010.00370.x

Ebrashi, R. E. (2010). Toward a behavioral theory of social entrepreneurship. Cairo, Egypt: $\mathrm{PhD}$ dissertation, German University in Cairo, Egypt.

Elster, J. (1989). Social norms and economic theory. Journal of Economic Perspectives, 3(4), 
99-117. https://doi.org/10.1257/jep.3.4.99

Fellnhofer, K., \& Puumalainen, K. (2017). Can role models boost entrepreneurial attitudes? International Journal Entrepreneurship and Innovation Management, 21(3), 274-288. https://doi.org/10.1504/IJEIM.2017.083476

Fink, A. (2003). The Survey Handbook. Thousand Oaks, CA: Sage: Sage. https://doi.org/10.4135/9781412986328

Fishbein, M. (1967). Readings in attitude theory and measurement. NY.

Flynn, B., Sakakibara, S., Schroeder, R., Bates, K., \& Flynn, E. (1990). Empirical research methods in operations management. Empirical research methods in operations management. Journal of Operations Management, 9(2), 250-284.

https://doi.org/10.1016/0272-6963(90)90098-X

Fornell, C., \& Larcker, D. (1981). Evaluating structural equation models with unobservable variables and measurement error. Journal of Marketing Research, 18(1), 39-50. https://doi.org/10.1177/002224378101800104

Gabriella Cacciotti, J. C., Mitchell, J. R., \& Giazitzoglu, A. (2016). A reconceptualization of fear of failure in entrepreneurship. Journal of Business Venturing, 31(3), 302-326. https://doi.org/10.1016/j.jbusvent.2016.02.002

Gardner, H. (2008). . A multiplicity of intelligences:. In tribute to professor Luigi Vignolo. .

Haines, R., Street, M., \& Haines, D. (2008). The influence of perceived importance of an ethical issue on moral judgment, moral obligation, and moral intent. Journal of Business Ethics, 81(2), 387-399. https://doi.org/10.1007/s10551-007-9502-5

Hair, J., Anderson, R. T., \& Black, W. (1998). (1998). Multivariate data analysis. New Jersey: USA: Englewood Cliffs.

Hair, J., Black, W., Basin, B., \& Anderson, R. (2010). Multivariate Data Analysis. New Jercy: Pearson Prentice Hall, Upper Saddle River.

Harjer, H., \& Habib, A. (2013). Factors of entrepreneurial intention of the public civil servant: empirical evidence in the case of Tunisia. nternational Journal of Business Management and Economic Research, 672-682.

Haugh, H. (2005). A research agenda for social entrepreneurship. Social Enterprise Journal, l(1), 1-12. https://doi.org/10.1108/17508610580000703

Hendry, J. (2004). Between enterprise and ethics: Business and management in a bimoral society. UK: Oxford University Press.

https://doi.org/10.1093/acprof:oso/9780199268634.001.0001

Hoffman, M. (2000). Empathy and moral development: Implications for caring and justice. London, England: Cambridge University Press. https://doi.org/10.1017/CBO9780511805851

Hooper, D., Coughlan, J., \& Mullen, M. (2008). Structural Equation Modelling: Guidelines 
for Determining Model Fit. Electronic Journal of Business Research Methods, 6(1), 53-60.

Houston, J., McIntire, S., Kinnie, J., \& Terry, C. (2002). A factorial analysis of scales measuring competitiveness. Educational and Psychological Measurement, 62(2), 284-298. https://doi.org/10.1177/0013164402062002006

Hu, L., \& Bentler, P. (1999). Cutoff Criteria for Fit Indexes in Covariance Structure Analysis: Conventional Criteria Versus New Alternatives,. Structural Equation Modeling, 6(1), 1-55. https://doi.org/10.1080/10705519909540118

Kandori, M. (1992). Social norms and community enforcement. The Review of Economic Studies, 59(1), 63-80. https://doi.org/10.2307/2297925

Kautonen, T., \& Tornikoski, S. L. (2010). Influence of work history on entrepreneurial intentions in prime age and third age: a preliminary study. International Small Business Journal, 28(6), 583-601. ttps://doi.org/10.1177/0266242610368592

Kinicki, A., \& Krietner, R. (2009). The nature of attitudes, organizational behavior. eGraw Hill Companies Inc.

Kirkley, W. W. (2016). Creating ventures: decision factors in new venture creation. Asia Pacific Journal of Innovation and Entrepreneurship, 10(1), 151-167.

https://doi.org/10.1108/APJIE-12-2016-003

Kirzner, I. (1979). Perception, Opportunity, and Profit. . Chicago IL.: University of Chicago Press.

Kirzner, I. (1999). Creativity and/or alertness: a reconsideration of the Schumpeterian entrepreneur. Review of Austrian Economics, 11(1-2), 5-17.

https://doi.org/10.1023/A:1007719905868

Kolvereid, L. (1996). Prediction of employment status choice intentions. Entrepreneurship Theory and Practice, fall, 47-57.

Lumpkin, G., \& Lichtenstein, B. (2005). The role of organizational learning in the opportunity recognition process. Entrepreneurship: Theory and Practice, 29(4), 451-472. https://doi.org/10.1111/j.1540-6520.2005.00093.x

Ma, Q., Chan, A. H., \& Chen, K. (2016). Personal and others facors affecting acceptance of smart phone technology by elder chinese adults. Applied Ergonomics, 54, 62-71. https://doi.org/10.1016/j.apergo.2015.11.015

Mair, J., \& Martí, I. (2006). Social entrepreneurship research: A source of explanation, prediction, and delight. Journal of World Business, 41(1), 36-44.

https://doi.org/10.1016/j.jwb.2005.09.002

Mair, J., \& Noboa, E. (2006). Social entrepreneurship: How intentions to create a social venture are formed. In M. R. Hockerts, Social entrepreneurship (pp. 121-135). New York: Palgrave Macmillan. https://doi.org/10.1057/9780230625655_8 
McQuitty, S. (2004). Statistical power and structural equation models in business research. Journal of Business Research, 57(2), 175-183.

https://doi.org/10.1016/S0148-2963(01)00301-0

Mehdivand, M., Zali, M., M.Madhoshi, \& Kordnaeiji, A. (2012). Intellectual capital and nano-business performance: the moderating role of entrepreneurial orientation. European Journal of Economics, Finance and Administrative Sciences, 1(52), 147-58.

Middleton, M. L.-K. (2015). Venture creation programs: bridging entrepreneurship education and technology. Education + Training, 57(1), 48-73.

https://doi.org/10.1108/ET-02-2013-0013

Miles, J., \& Shevlin, M. (2007). A time and a place for incremental fit indices,. Personality and Individual Differences, 42(5), 869-874. https://doi.org/10.1016/j.paid.2006.09.022

Mitchell, R., Busenitz, L., Lant, T., McDougall, P., Morse, E., \& Smith, J. (2004). The distinctive and inclusive domain of entrepreneurial cognition research. Entrepreneurship: Theory and Practice, 28(6), 505-518. https://doi.org/10.1111/j.1540-6520.2004.00061.x

Morissette, D., \& Gingras, M. (1989). Bruxelles: De Boeck.

Nga, J. K., \& Shamuganathan, G. (2010). The Influence of Personality Traits and Demographic Factors on Social Entrepreneurship Start Up Intentions. Journal of Business Ethics.

Nicholls, A. (2006). Social Entrepreneurship: New Models of Sustainable Social Change. New York, NY: Oxford University Press.

Nieto, M., \& González-Álvarez, N. (2014). Social capital effects on the discovery and exploitation of entrepreneurial opportunities. International Entrepreneurship Management Journal, 12, 507-530. https://doi.org/10.1007/s11365-014-0353-0

Nunally, J., \& Bernstein, I. (1978). (1978). Psychometric theory. New York: McGraw-Hill. New york: McGraw-Hill.

Olugbola, S. A. (2017). Exploring entrepreneurial readiness of youth and startup success components: Entrepreneurship training as a moderator. Journal of Innovation \& Knowledge, 155-177.

Othman, N., Hashim, N., \& Wahid, H. A. (2012). Readiness towards entrepreneurship education: Students and Malaysian universities. Education + Training.

https://doi.org/10.1108/00400911211274837

Pituch, K. A., \& Stevens, J. P. (2016). Applied multivariate statistics for the social sciences. New York: Routledge.

Primack, B., Switzer, G., \& Dalton, M. (2007). Improving measurement of normative beliefs involving smoking among adolescents. Arch. Pediat Adolesc. Med., 161(5), 434-439. https://doi.org/10.1001/archpedi.161.5.434 
Roberts, B., \& Woods, C. (2000). Changing the world on a shoestring: Th e concept of social entrepreneurship. . University of Auckland Business Review, 45-51.

Rotter, J. (1966). Generalized expectancies for internal versus external control of reinforcemen. Psychological Monographs, 1, 80.

Ruskin, J., Seymour, R. G., \& Webster, C. M. (2016). Why Create Value for Others? An Exploration of Social Entrepreneurial Motives. Journal of Small Business Management .

Salovey, P., \& Mayer, J. (1990). Emotional Intelligence. Cognition, and Personality.

Schumpeter, J. (1934,2004). The Theory of Economic Development. Piscataway, NJ: Transaction Publishers,.

Segal, E. A. (2011). Social Empathy: A Model Built on Empathy, Contextual Understanding, and Social Responsibility That Promotes Social Justice. Journal of Social Service Research, 37, 266-277. https://doi.org/10.1080/01488376.2011.564040

Shane, S. (1993). Cultural influences on national rates of innovation. Journal of Business Venturing, $59 \mathrm{e} 73$.

Shane, S., \& Venkataraman, S. (2000). The promise of entrepreneurship as a field of research. Academy of Management Review, 25(1), 217-226. https://doi.org/10.5465/amr.2000.2791611

Solesvick, M. Z. (2012). Entrepreneurial motivations and intentions: investigating the role of education major. Education + Training, 55(3), 253-271.

https://doi.org/10.1108/00400911311309314

Solesvik, M., Westhead, P., Kolvereid, L., \& Matlay, H. (2012). "Student intentions to become selfemployed: employed: the Ukrainian context", . Journal of Small Business and Enterprise Development, 19(3), 441-460. https://doi.org/10.1108/14626001211250153

Sølvberg, A. (2003). Sølvberg, A. (2003). Computer-related control beliefs and motivation: A panel study. Journal of Research on Technology in Education, 35(4), 473-482.

https://doi.org/10.1080/15391523.2003.10782397

Stegier, J. (2007). Understanding the limitations of global fit assessment in structural equation modeling. Personality and Individual Differences, 42(5), 893-898.

https://doi.org/10.1016/j.paid.2006.09.017

Tabachnick, B., \& Fidell, L. (2007). Using Multivariate Statistics (5th ed.). New York: (5 ed.). Newyork: Allyn and Bacon.

Thompson, J. (2008). Social enterprise and social entrepreneurship: Where have we reached?. Social Enterprise Journal, 4(2), 149-161. https://doi.org/10.1108/17508610810902039

Thorndike, R., \& Stein, S. (1937). An evaluation of the attempts to measure social intelligence. Psychological Bulletin. https://doi.org/10.1037/h0053850

Tkachev, A., \& Kolvereid, L. (1999). Self-employment intentions among Russian students. Entrepreneurship and Regional Development, 11(3), 269-280. 
https://doi.org/10.1080/089856299283209

Trivedi, C. (2010). A social entrepreneurship bibliography. Journal of Entrepreneurship. https://doi.org/10.1177/097135570901900105

Urban, B. (2008). Social entrepreneurship in South Africa: Delineating the construct with associated skills. International Journal of Entrepreneurial Behaviour \& Research. https://doi.org/10.1108/13552550810897696

Visser, P., \& Krosnick, J. (1998). cycle: Surge and decline. Journal of Personality and Social Psychology, 75(6), 1389-1398. https://doi.org/10.1037/0022-3514.75.6.1389

Weerawardena, J., \& Mort, G. (2006). Investigating social entrepreneurship: A multidimensional model. Journal of World Business, 21-35.

https://doi.org/10.1016/j.jwb.2005.09.001

Yordanova, D., \& Tarrazon, M. (2010). Gender differences in entrepreneurial intentions:evidence from Bulgaria. Journal of Developmental Entrepreneurship, 15(3), 245-261. https://doi.org/10.1142/S1084946710001543

Zampetakis, L., Kafetsios, K., Bouranta, N., Dewett, T., \& Moustakis, V. (2009). On the relationship between emotional intelligence and entrepreneurial attitudes and intentions. International Journal of Entrepreneurial Behaviour \& Research, 15(6), 595-618.

https://doi.org/10.1108/13552550910995452

Zhao, H., Seibert, S., \& Hills, G. (2005). The mediating role of self-efficacy in the development of entrepreneurial intentions. Journal of Applied Psychology, 90(6), 1265-1275. https://doi.org/10.1037/0021-9010.90.6.1265

Zhao, X., Sayeed, S., Cappella, J., Hornik, R., Fishbein, M., \& Ahern, R. (2006). Targeting norm-related beliefs about marijuana use in an adolescent population. Health Commun. , 19(3), 187-196. https://doi.org/10.1207/s15327027hc1903_1

Zimmerman, R. (2008). Understanding the impact of personality traits on individual's turnover decision. A metal analytical model. Journal of Personnel Psychology, 61(2), 309-348. https://doi.org/10.1111/j.1744-6570.2008.00115.x

\section{Copyright Disclaimer}

Copyright for this article is retained by the author(s), with first publication rights granted to the journal.

This is an open-access article distributed under the terms and conditions of the Creative Commons Attribution license (http://creativecommons.org/licenses/by/3.0/). 